\title{
The policy on agricultural land and its impact on agricultural production and peasant's life in Vietnam
}

\author{
Van Duc Pham ${ }^{1,2 *}$ and Victor Barkhatov ${ }^{3}$ \\ ${ }^{1}$ Vietnam Academy of Social Sciences, No1, Lieu Giai St, Badinh Dist, Hanoi, 10000, Viet Nam \\ ${ }^{2}$ Graduate Academy of Social Sciences, 477 Nguyen Trai street, Thanh Xuan district, Hanoi, 10000, \\ Vietnam \\ ${ }^{3}$ Chelyabinsk State University, Br. Kashirinykh str., 129, Chelyabinsk, 454001, Russia
}

\begin{abstract}
The paper analyzes the key contents of the policies on agricultural land of the State of Vietnam today, such as, the tenure of agricultural land ownership, the State's guidelines on land price, the policy on concentration and accumulation of agricultural land, the policy on agricultural land tax and policy on compensation for agricultural land recovery. Then the paper process to evalute the impact of Agricultural Land Policies to Vietnam's Agriculture in the Renovation Period as well as the Impact of Agricultural Land Policies on Agricultural Land Fund. The paper also analyzes both the positive impacts and unexpected impacts of Land Policies on the Peasant Life. Through the research the paper comes to the conclusion that despite many outstanding achievements of renovated management policies on the agricultural land, there will be new issues and problems relating to policies on land, which should be addressed timely and prorperly in order to help Vietnam develop its modern and sustainable agriculture.
\end{abstract}

\section{Introduction}

Agricultural land is the most valuable natural resource in Vietnam. Agricultural land is one of the most decisive resources for the life and development of the peasants in the context of socialist-oriented market economy in Vietnam today. Since the beginning of the Renovation, the State has issued policies to help the peasants to get access to land use rights. Those policies exerted positive impacts on agricultural land and agriculture in general in Vietnam. However, in order to make its agriculture develop stronger and more sustainable Vietnam should be ready to deal timely and properly with many new issues relating to the policy on land in its future development.

\section{Materials and methods}

The authors uses analytical and qualitative research methods to analyzes and evaluate the

\footnotetext{
${ }^{*}$ Corresponding author: ducphilosophy@yahoo.com
} 
current policies on agricultural land in Vietnam, which are the concrettation of the Law on Land from 1993 to 2013. The materials and methods used in this paper is to focus on the key contents of the policies on agricultural land of the State of Vietnam today: the tenure of agricultural land ownership, the State's guidelines on land price, the policy on concentration and accumulation of agricultural land, the policy on agricultural land tax and policy on compensation for agricultural land recovery

\section{Discussion and Research Results}

\subsection{Policies on Agricultural Land in Vietnam Today}

The current policies on agricultural land in Vietnam were the results of the Renovation Process initiated by the Politburo Decision No.10 issued in 1988 on the handle of selfmastership rights to peasant's households, the Decision of the Sixth Plenum of Sixth Central Committee of the Communist Party of Vietnam (November, 1988) on the handle of land to peasant's households. Those policies were concretized in Law on Land issued in 1993 (which has been continuously revised in following years, especially the 2003 and 2013 Law on Land), the Law on Land Use Transfer Tax (1999), the Law on Agricultural Land Use Tax (in 2000, replacing agricultural land Tax). The key contents of the policies on agricultural land of the State of Vietnam today are expressed in the tenure of agricultural land ownership, the State's guidelines on land price, the policy on concentration and accumulation of agricultural land, the policy on agricultural land tax and policy on compensation for agricultural land recovery.

Agricultural Land Ownership Tenure. The tenure of agricultural land ownership in Vietnam is expressed concentratedly in two rights: Ownership right and use right. The State, the subject of ownership right (land belongs to the entire people with the State as the representative owner), the masses, mainly peasants are subject of the land use right. That kind of ownership tenure is specific in comparison with many countries in the world.

As the owner and the organ of public management of land, the State has the right: To recover peasant's land use right, to decide conversion of agricultural land use purpose and transfer of agricultural land, the use of which has been conversed, to organizations and individuals who are not peasants and to determine prices of the recovery of agricultural land.

Peasants can use agricultural land for agricultural production purposes. Apart from their use right, peasants also have the right to transfer, inherit and mortgage their use right. According to the current laws the term for leasing agricultural land to peasants is 50 years for land using for planting perennial crops and 20 years for other lands.

The 2013 Land Law devotes the entire Chapter XI on the rights and obligations of land users. Under the law, land users have their right to transfer their land use rights and the duty to implement all rights and obligations written in the law. Their land use rights are protected by the law. Under the 2013 Land Law, land use rights also included the rights to transfer, exchange, lease, inherit and mortgage.

The Policy on Agricultural Land Price. According to 2013 Land Law, the land price is based on the land use specified on the land use certificate, land tenure and to remain close to the market price or the income generated from the land. The land price table is changed every five years and is adjusted when there is a large change in the market.

While officially recognizing market prices on land and regulate State's prices to meet market price, the State recognizes indirectly the existence of land use prices and land use market. This is one of the bases for the State to determine the prices of land exchange between the State and the citizens. 
Policies on Encouraging Land Accumulation and Collection. The handle of the land to peasant' households was initiated in the beginning of $1990 \mathrm{~s}$ in accordance with an egalitarian mechanism on both the quantity and quality of land. As a result, agricultural land handed to peasants became too divided. To promote the farmers to conduct large scale agricultural production, the State has provided a policy to encourage farmers - "exchange farming fields," thereby, farmers can transfer or exchange land with one another to own larger and more collective agricultural fields.

Policies on Agricultural Land Withdrawal and Compensation. The 2003 Law on Land determines that the State has the right to recover agricultural land use rights, as well as housing land of farmers for objectives of public interest, or socio-economic development

While recovering peasants' agricultural land and housing land, the State must compensate peasants by way of allocation of new land for the same purpose as the type of land which was recovered or shall be paid compensation equal to the value of land use rights as at the time when the decision on recovery is made where no land is available for compensation.

Since 1990s the State has recovered many agricultural lands in order to develop new industrial zones and urban squares.

In the new Land Law (2013) the State will only acquire land from individuals or organizations for national defense or security objectives and for the socio-economic developmental interests of the nation or people.

Land acquisitions must be done in a manner of transparency and accountability and compensation be paid in accordance with the laws.

A key purpose of having such tight regulations on land acquisition for socio-economic projects (in the interest of the nation and the people) is to restrain abuses of power and corruption.

Policies on Agricultural Land Tax. While using the land, peasants must pay to the State the tax on: land lease, land use and other administrative fees. In general, the total of agricultural land tax is not big. From 2003 to 2010, the Government decided to exempt tax for agricultural land under the land limits for all peasants and completely exempt land use tax for poor peasant households and reduce 50\% tax for using the land in excess of the land limits.

The land tax is applicable only for using the land in excess of the land limits or auctioned land. All fees are small often paid for the certificate of land use right, mapping, land registration.

In general, policies on agricultural land tax have been streamlined remarkably, including tax exemption with transactions of farming land transfers with a view to encouraging land accumulation and collection by farmers, and exemption with land.

\subsection{The Impact of Agricultural Land Policies to Vietnam's Agriculture in the Renovation Period}

In the Renovation Period we can see the impact of Agricultural Land Policies to Vietnam's Agriculture. Thanks to the new Government's policy on agricultural land, Vietnam's agriculture has enjoyed positive changes in population and labor forces. In $199080 \%$ of the population of Vietnam (66 millions) lived in rural areas. In 2008 the rural population only consisted of $72 \%$ of the whole population. Together with the increase of rural population from 58.9 million in 2000 to 62 million in 2008, there was a strong process of re-structure of labors in agricultural, forestry and aqua-cultural areas. The movement of labor forces from rural areas contributed to the enlargement of average land area per agricultural laborer from 0.9 hectares in 2000 to more than 1.1 hectares in 2008.

The above-mentioned changes confirm the rightness of the economic renovations and 
the process of international integration of Vietnam in general and policies on agricultural land in particular. However, the most significant achievement of Vietnam agriculture during the last two decades is attached to foods. During 1970s and 1980s Vietnam often suffered from food shortage and hunger, in 1976 Vietnam had to import 148 thousand tons of rice and in 1986 that number was 483 thousand tons. After implementing the Renovation policy, the agricultural production has increased remarkably. The rice import was reduced to 55 tons in 1989 and there was no rice import in 1990. In 1995 the total food production reached 26 million tons (among which 25million tons of rice). In 2008 the total food production was 43 million tons (39 million tons of rice. The average food production per person increased from $363 \mathrm{~kg}$ per person in 1995 to $502 \mathrm{~kg}$ per person in 2008 and in 2012 the food production was about 43.4 million tons, more than one million in comparison with the production of 2011.

Since 1990 Vietnam had produced enough foods for the population, and exported at least more than 5 million tons of rice each year together with other agricultural products like coffee, pepper, nuts, seafood products in 2012 Vietnam exported 7.7 million tons of rice.

In 2007 the total value of agricultural export consisted of 19\% among 48.4 billion US Dollars of exports. At the same time, Vietnam also imported some foods, which consisted about $6 \%$ in total of 60.8 billion US Dollars of exports.

The supply of foods has increased gradually and led to the improvement of the situation of key areas in social welfare and economy. The criteria reflecting that fact can be seen in the increase of life expectancy (effected by the rate of infant death) and rate of death of children less than 5-year-old (decided by nutrition and health care). The average life expectancy increased from 60 years in 1980 to 65 years in 1990, 69 in 2001, 70 years in 2004 and 74 years in 2007. The current average life expectancy of the Vietnamese is 75 years, which is more than 33 years in comparison with the rate of 1960, while the average increase of life expectancy in the world for that period is only 21 years.

The rate of death of children less than 5 years old reduced from 70/1000 in 1980 to $56 / 1000$ in 1995, 38/1000 in 2004 and 15/1000 in 2005. The rate of death of children less than five years old and one year old reduced from $35 \%$ and $45 \%$ in 2001 to $16 \%$ and $26 \%$ in 2005 .

The above-mentioned achievements are very significant and they are closely related to the positive changes of agricultural land fund in Vietnam.

\subsection{The impact of Agricultural Land Policies on Agricultural Land Fund in Vietnam.}

The land in Vietnam is officially divided into agricultural land, non-agricultural land and unused land. Agricultural land category, comprises the following types of land: Land for agricultural cultivation, forest land, land for aquaculture, land for salt production. Agricultural land is divided further into Land for planting perennial crops and land for planting annual crops, which is further divided into land for rice and short-term crops. Forest land is divided into protective forest land and specialized use forest land. The classification of the land serves the basis for land management and planning.

While evaluating the plan for land use for the period from 2001 to 2010, the Economic Committee of the National Ensemble confirmed that for that period the planning of land use played an important role in the enhancement of the efficiency and effect of State's management on land and contributed to bringing into full play land potentials to serve socio-economic objectives, create new jobs, increase incomes and improve people's life. Land use planning has zoned land fund for agricultural production, protected land fund for rice cultivation, ensured the goal of providing sufficient foods for the country, sufficient 
resources for strategic reservation and export. The work on protection and development of forests brings about positive changes preventing serious degeneration of forest areas. Land use planning also has met the demands for promotion of the cause of national industrialization, modernization and urban development; created important resources for national socio-economic development through the activities of auction, collecting fees in land handling, land lease, change of purposes of land use; the areas of unused land are gradually exploited and brought into use rationally to meet the demands for land use for socio-economic development and ensure the ecological balance and environmental protection.

However, the practice shows that the quality of prediction of demands for land funds for development of branches and sectors, investment projects in order to include into land use plans in local authorities is still lacking of scientific calculation and is away from development strategies and demands. There have not yet been clearly defined responsibilities of every level in management, organization, planning and implementation of adopted plans for land use.

Although the land for wet-rice cultivation reached 103.55\% (more than the planned target), during the last 10 years the area of 270 thousand hectares had conversed into the land used for other purposes. The conversion of the land specialized in wet-rice cultivation into the land for industrial and urban development instead of using other lands (for that purpose) took place in many localities. The land for industrial zones and parks were met sufficiently $(100 \%)$ but investment was still fragmented, some industrial zones were developed too slow.

\subsection{Meeting the Demands for Infrastructure Development and Ensuring Food Security}

With the land use plan extended into 2020 and the five-year land use plan (2011-2015), the Government proposes three key objectives: to meet the demand of infrastructure development (in areas of: transport, water-resources, culture, health care, sports, etc.); to promote industrial and urban development in order to carry out the national cause of industrialization and modernization to ensure national security and defense and social welfare; to ensure the national food security; to protect the environment and promote sustainable development to meet with climate change.

Accordingly, the Government proposes the concrete project of land use planning. By the year of 2020 the agricultural land will be 26.732 thousand hectares, which is more than 506 thousand hectares in comparison with that of 2010. By the year 2020 the non-agricultural land will be 4.880 thousand hectares, which is more than 1.175 thousand hectares in comparison with that of 2010. The unused land at the 2010 was 3.164 thousand hectares and as the result of conversion into agricultural and non-agricultural purposes by the year of 2020 the unused land will only be 1.483 thousand hectares.

The Government also proposes to retain 3.81 million hectares for rice cultivation by 2020. But according to local proposals the area for rice cultivation will only be 3,6 million hectares. The Economic Committee of the National Ensemble agreed with the Government's proposal to retain 3.81 million hectares for rice cultivation in 2020 . The Government's proposal should point out concrete measures to retain that area for rice cultivation, and at the same time, have special policies for rice cultivators and the localities that retain the area for rice cultivation.

Relating to Government's proposal that the area for industrial zone will be 200 thousand by 2020, after consideration the Economic Committee of the National Ensemble agreed with the Government's proposal but requires the Government should only recover lands in accordance with real demands and pay attention to local authorities and regions (middle 
land, mountain and coast-line regions), which can transform their economic structure.

\subsection{Positive Impacts and Unexpected Impacts of Land Policies on the Peasant Life Today}

Agricultural land policies in Vietnam have impacted positively on agricultural production and the life of peasants today in following ways:

- Facilitating peasants to be pro-active in their labor, production and transactions in order to maximize the efficiency of agricultural production and income generation from land.

Vietnamese peasants get three benefits from agricultural land policies: agricultural land is handled to them free of charge; have the right to organize and plan their cultivation and sell agricultural products in accordance with market principles in order to improve their life; have the right to transfer land use right as a property. As a result, peasant's life is significantly improved.

- Land policies have also allowed farmers to shift their economic structure, and to enhance land use effectiveness.

As peasant's households are regarded as autonomous economic unit, peasants are free to choose to engage in the appropriate agricultural production activities that could bring them benefits and good incomes. As a result, in Vietnam there exist variety of agricultural production, many households specialize in agricultural product goods, the number of households specializing in rice are reduced.

- Land policies also allow credit access for farmers,

The issue of certificate on agricultural land use right for peasants helps them not only make the practice of land use right transaction safe, especially transactions relating to lease, production capital but also mortgage their land use right for credits and loans.

- Land policies have encouraged farmers to accumulate collective agricultural land for better agricultural cultivation and production.

According to the Law on Land, peasants can exchange, transfer, lease their land in order to have large amount of agricultural land appropriate for mechanization and better agricultural cultivation as well as applying scientific methods for their cultivation. Those peasants, who are not able to engage in effective agricultural activities, can transfer their agricultural land use right to other peasants in order to have money to start non-agricultural industries.

- Land policies have activated agricultural land market in rural areas, resulting in more efficient farming land allocation, and emergence of new industries in rural areas.

The market for agricultural land use right in rural areas has been established to facilitate transactions on land use right and reduce exchange fees. The fact that the transfer of agricultural land use right becomes easier creates favorable conditions for rational use of land in accordance with market regulations. As a result, this promotes the process of land re-allocation: between cultivation, aqua-cultivation and animal husbandry, and at the same time, contribute to restore and develop many traditional handicraft villages in rural areas in Vietnam.

In addition to positive effects, there are still several adverse impacts from farming land policies.

- Peasants enjoy limited benefits and profit from their land use rights. According to the Law on Land, peasants cannot freely change agricultural land into other types of land, and at the same time, due to the low benefit generation of agricultural land, the price of agricultural land use right is much lower than the price of use right of other lands. The term for agricultural land use is too short and in addition, the compensation rate for agricultural land is too low if agricultural land is recovered by the State to use for other purposes. As a 
result, the peasants are not strongly attached to agriculture and the chance to getting rich from agriculture is difficult.

- The situation in which peasants do not have land for cultivation is increasing. The peasants have rights on land use. However, in difficult circumstances many families, who do not have enough capital or appropriate ways to cultivate and produce, have no other choice but to sell their agricultural land use right and then fall into poverty. The State does not have enough resources to help them to retain agricultural land as the means of their living. As a result, the gap between the rich and the poor generates within the class of peasants. Social evils and crimes have chances to penetrate into the life of Vietnam villages.

- Agricultural land policies fail to encourage farmers to protect cultivated land and to make long-term investment in land.The fact that term for land use right is too short cannot encourage peasants to make long-term investment in order to protect agricultural land. At the same time, in order to have better crops many peasants abuse chemical fertilizers and ignore investment on long-term improvement. As a result, agricultural land becomes degenerated and even polluted.

- Effects of the policies on supporting farmers to accumulate and to collect farming land remains unsatisfied.The egalitarian policy to handle land of 1990s had contributed to agricultural land to become fragmented. In addition, the conversion of use of large amount of agricultural land into other purposes has led to the continuous reduction of scope of agricultural land per person. At the moment, there exist only few agricultural production units with the total amount of land of 3 to 5 hectares, the majority of households now possess less than one hectare.

- Policies on land withdrawal and compensation make peasants suffer from certain losses. If their land is recovered, peasants will suffer from certain losses because the State has not enough agricultural land fund to compensate peasants. The land reserved for compensation is often not good as the recovered land. As the result, the peasant's life may become more difficult. Peasants in some cases cannot negotiate about compensation. Policies on vocational training for peasants, whose lands have been recovered, as well as policies on encouraging individuals and organizations, who get land use right from recovered agricultural land of peasants, to share and help peasants, the policies on resettlement often bring low effect.

- Policies fail to encourage farmers to practice modern agricultural production. As the agricultural land is too fragmented, almost all agricultural households use their family's labors to cultivate and do not intend to buy agricultural machines and modern devices. They do not intend to cooperate with one another in agricultural production activities, in exchange of means of production and selling agricultural products as well as in application of science and technology in their agricultural production. Therefore, the effect and performance of agricultural production is still low.

\section{Conclusion}

The Cause of Comprehensive Renovation in Vietnam has brought about a new face for Vietnam's agriculture and rural life as well as facilitated a change of historical significance. From a country, which used to suffer from food shortage and imported food grains, Vietnam became one of the two largest rice exporters in the world. That outstanding achievement has been the result of renovated management policies, first of all, policies on the agricultural land. However, the process of continuous renovation has posed new issues and problems relating to policies on land in order to help Vietnam develop its modern and sustainable agriculture. And we can see that a very important objective of 2013 Land Law is to strengthen the oversight role of the National Assembly, the People's Councils at 
different levels, the Viet Nam Fatherland Front, social organizations and people on the land management and land use schemes.

\section{References}

1. C.M. Ho, Complete Work (National Publishing House, Hanoi, 1995)

2. D. Müller, D.K. Munroe, Interfacing Geostatistics and GIS (Springer, Berlin, Heidelberg, 2009) DOI: 10.1007/978-3-540-33236-7_8

3. Communist Party of Vietnam, The Documents of the 11th Party's Congress (National Political Publishing House, Hanoi, 2011)

4. Communist Party of Vietnam, The Documents of the 12th Party's Congress (National Political Publishing House, Hanoi, 2016)

5. N.S. Van, Journal of Southeast Asian Studies 4, 309-334 (2007)

6. Q.T. Nguyen, Quang Tuyen, ASLI Working Paper 15 (2010)

7. N.T. Phat, N.T. Dung, Transit Stud. Rev. 18, 377-383 (2011) DOI: 10.1007/s11300011-0213-3

8. World Bank Vietnam, Embassy of Denmark, and Embassy of Sweden. Recognizing and Reducing Corruption Risks in Land Management in Vietnam (Hanoi, 2013)

9. World Bank, World Bank Policy Note (Hanoi, 2012)

10. R. Friederichsen, T.T. Minh, A. Neef et al., Agric Hum Values 30, 555-568 (2013) DOI : 10.1007/s10460-013-9433-y

11. L.D. Khai, T. Markussen, S. McCoy, F. Tarp, Land Tenure Reform in Asia and Africa (Palgrave Macmillan, London, 2013) DOI : 10.1057/9781137343819_7

12. P. Nguyen-Van, N. To-The, Rev. Agric. Food Environ. Stud. 97, 173-184 (2016) DOI : 10.1007/s41130-016-0026-1 